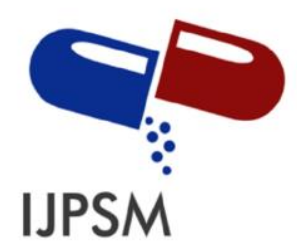

Restia Apriliana et al, Int. Journal of Pharmaceutical Sciences and Medicine (IJPSM),

Vol.6 Issue. 8, August- 2021, pg. 144-151

ISSN: 2519-9889

Impact Factor: 3.426

\title{
EFFECTS OF ANTI-INFLAMMATORY AND ANTIOXIDANT ACTIVITIES OF LANTANA (Lantana Camara L)
}

\author{
Restia Apriliana ${ }^{1}$; Yufri Aldi ${ }^{2}$; Sri Oktavia ${ }^{1}$ \\ ${ }^{1}$ School of Pharmaceutical Science (STIFARM), Siteba Kurao Pagang Street, Padang, 25147, Indonesia \\ ${ }^{2}$ Faculty of Pharmacy Andalas University (UNAND), Limau Manis, Padang, 25175, Indonesia \\ For correspondence: Tel. +(62)85274558508, Email: yufrialdi@gmail.com \\ DOI: 10.47760/ijpsm.2021.v06i08.010
}

\begin{abstract}
Lantana camara is a plant that is used empirically for traditional medicine. This plant has the potential to be developed as an anti-inflammatory and antioxidant drug because it contains flavonoids, saponins, tannins, alkaloids $^{[1]}$ essential oils ${ }^{[19]}$, carbohydrates, proteins, glycosides, oligosaccharides, kinins, steroids, triterpenoids, and sesquiterpenes ${ }^{[2]}$. Therefore this article is created in order to provide information about the various research that supports evidence of conformity with the use of this plant empirically as antiinflammatory and antioxidant. Antioxidant activities were obtained in Lantana camara plants by using the DPPH method which showed high $\mathrm{IC}_{50}$ values compared to the standard drug. The anti-inflammatory activity of lantana leaves showed that they had different anti-inflammatory effects depending on the dose given. From the results of the review, empirical evidence of pharmacological activity was found from the use of the lantana plant leaves.
\end{abstract}

Keywords: Anti-inflammatory, antioxidant, Lantana camara, phytochemicals

\section{Introduction}

Currently, the popularity of herbal therapies is increasing. One of the medicinal plants that are empirically and commonly used as traditional medicine is lantana leaves (Lantana camara $L)^{[1]}$ from the Verbenaceae family. This plant has been used in many parts of the world to treat various diseases ${ }^{[2]}$. In Central and South America lantana leaves can treat wounds, chickenpox, and measles. In Asian countries, the lantana leaves are used to treat wounds, rheumatism, boils, leprosy, and scabies ${ }^{[3]}$. In Ghana an infusion of the whole plant is used for bronchitis and pulp of the root in milk is given to children to treat stomach aches ${ }^{[21]}$. Empirically, lantana leaves are used by the community to treat several kinds of diseases such as wound medicine, cough medicine, urine laxative, sweat laxative, menstrual laxative, fever reducer, swelling medicine, gout, and ulcers ${ }^{[2]}$, skin diseases, pain relievers, vaginal discharge, tuberculosis, and asthma ${ }^{[1]}$, bleeding cessation for cuts, tinea versicolor, ringworm, and ringworm ${ }^{[22]}$.

Lantana leaves contain active compounds of flavonoids, saponins, tannins, alkaloids ${ }^{[17]}$ essential oils, carbohydrates, proteins, glycosides, oligosaccharides, kinins, steroids, triterpenoids, and sesquiterpenes ${ }^{[2]}$. The content of saponins, flavonoids, and essential oils has anti-inflammatory effects such as the mechanism of action of saponins that are able to interact with many lipid membranes, flavonoids with the mechanism of 


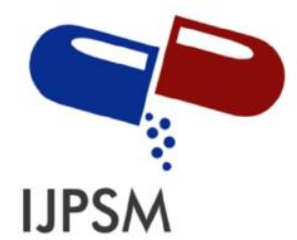

\section{Restia Apriliana et al, Int. Journal of Pharmaceutical Sciences and Medicine (IJPSM), Vol.6 Issue. 8, August- 2021, pg. 144-151}

action of inhibiting the metabolic pathway of arachidonic acid, the formation of prostaglandins, if prostaglandins are not inhibited, there will be an increase in body temperature which will cause fever ${ }^{19]}$, essential oils with a mechanism that can inhibit platelet aggregation by inhibiting thromboxane so that it also plays a role in anti-inflammatory effects ${ }^{[4]}$. The content of secondary metabolites that can function as antioxidants includes alkaloids, flavonoids, phenolic compounds, steroids, and terpenoids ${ }^{[2]}$.

Antioxidant compounds from plants can be obtained by extraction using a solvent. The difference in polarity of the solvent results in different amounts and types of metabolites obtained ${ }^{[5]}$. The use of antioxidant compounds is growing both for food and medicine along with increasing knowledge about free radical activity ${ }^{[6]}$. Antioxidant compounds are inhibitors used to inhibit autoxidation. The antioxidant effect of phenolic compounds is due to their oxidizing properties which play a role in neutralizing free radicals ${ }^{[7]}$. Natural antioxidants that can be obtained from medicinal plants play an important role in preventing the treatment of chronic diseases caused by oxidative stress. Exogenous intake of antioxidants has been shown to prevent inflammation ${ }^{[6]}$.

Inflammation is a natural response that occurs in tissue damage ${ }^{[8]}$. Inflammation is one of the diseases that many people suffer from. Inflammation has a fairly high incidence, inflammation can be caused by physical trauma, infection or antigen reactions from disease, such as being hit by a blunt object and bacterial infection in open wounds (pus formation on the skin). wounds) which can cause pain and interfere with activities ${ }^{[9]}$. Inflammatory reactions can be observed from clinical symptoms, namely, redness (rubor), increased heat (kalor), swelling (tumor), pain (dolor) ${ }^{[10]}$. Currently, there are various drugs used to treat inflammation. Antiinflammatory steroids, for example, can cause decreased immunity to infection, osteoporosis, atrophy of muscle and fat tissue, increase intraocular pressure, and are diabetic ${ }^{[14]}$. The steroid class anti-inflammatory can cause gastric ulcers to bleeding ${ }^{[15]}$, kidney disorders, and anaemia ${ }^{[16]}$. Long-term use of NSAIDs can cause ulceration and bleeding in the lower gastrointestinal tract. It was reported that NSAIDs cause surface wounds by affecting the integrity of the mucous membrane of the gastrointestinal tract ${ }^{[10]}$. So for the development of traditional medicine and with the strong indication that lantana leaves have anti-inflammatory and antioxidant activities, further research needs to be developed in order to know whether or not lantana leaves can inhibit inflammation and have antioxidant activity. Free radicals are atoms or molecules that have lost electrons in their outer orbits ${ }^{[18]}$.

Free radicals can be generated from aerobic respiration and various other metabolic processes in the body ${ }^{[2]}$. If the level of free radicals in the body is too high, it can reduce cell function and induce ${ }^{[6]}$. If cell damage occurs continuously, there will be an imbalance in the number of free radicals in the body so that it can cause inflammation in cells ${ }^{[22]}$, causing degenerative diseases such as cancer, cardiovascular disease, Parkinson's and Alzheimer's. One way to prevent excessive free radicals in the body is by giving antioxidants ${ }^{[25]}$. Antioxidants are compounds that can neutralize the reactivity of free radicals. There are several exogenous synthetic compounds that can be used as antioxidants, namely vitamin E and BHA (Butylated Hydroxyanisole). Therefore, we look for antioxidants that come from nature to reduce the toxic effects ${ }^{[22]}$.

\section{Data Collection Methods}

In compiling this review article, the literature sources used were official books and international journals with the topic of anti-inflammatory activity and chemical compounds contained in the lantana leaves plant (LantanaCamara) published in the last 20 years (2000-2000). 2020). The main reference search for this review article was done through websites such as Science Direct, Google Scholar, PubMed, and various other published journals. Keywords used to search the data were as follows: "Anti-inflammatory, antioxidant, Lantana camara, phytochemical" 


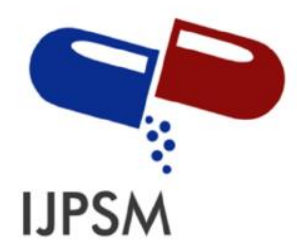

Restia Apriliana et al, Int. Journal of Pharmaceutical Sciences and Medicine (IJPSM),

Vol.6 Issue. 8, August- 2021, pg. 144-151

ISSN: 2519-9889

Impact Factor: 3.426

\section{Result and Discussion}

\subsection{Anti-inflammatory}

The anti-inflammatory activity of lantana leaves has been demonstrated in both in vitro and in vitro studies. A total of 5 studies were included in this article based on our eligibility criteria. The anti-inflammatory activity of lantana leaves is summarized in table 1 .

Table 1. Summary on anti-inflammatory activity of Lantana camara

\begin{tabular}{|c|c|c|c|c|c|}
\hline Type of extract & $\begin{array}{l}\text { Dose/concentrat } \\
\text { ion of }\end{array}$ & animal & Pharmacological activity & country & Reference \\
\hline Ethanol extract & $\begin{array}{l}100 \mathrm{mg} / \mathrm{kg} \mathrm{BW} \\
200 \mathrm{mg} / \mathrm{kg} \mathrm{BW} \\
400 \mathrm{mg} / \mathrm{kg} \mathrm{BW}\end{array}$ & $\begin{array}{l}\text { Male } \\
\text { white rats }\end{array}$ & $\begin{array}{l}\text { Ethanol extract of lantana } \\
\text { leaves has an inhibition effect } \\
\text { for inflammation in male } \\
\text { white rats and has an } \\
\text { influence on the inhibition of } \\
\text { the cyclooxygenase- } 2 \text { enzyme } \\
\text { in male white rats }\end{array}$ & Indonesian & $\begin{array}{l}\text { Ifora et al, } \\
2020\end{array}$ \\
\hline Methanol extract & $\begin{array}{l}750 \mathrm{mg} / \mathrm{kg} \mathrm{BW} \\
1000 \mathrm{mg} / \mathrm{kg} \mathrm{BW} \\
1250 \mathrm{mg} / \mathrm{kg} \mathrm{BW} \\
1500 \mathrm{mg} / \mathrm{kg} \mathrm{BW}\end{array}$ & White rats & $\begin{array}{l}\text { Methanol extract in lantana } \\
\text { leaves has better anti- } \\
\text { inflammatory activity in } \\
\text { reducing inflammation of } \\
\text { edema in the feet of white } \\
\text { rats, the dose used shows a } \\
\text { decrease in inflammation of } \\
\text { the feet of white rats. }\end{array}$ & Indonesia & $\begin{array}{l}\text { Wijaya et al, } \\
2017\end{array}$ \\
\hline Ethanol extract & $\begin{array}{l}3.2 \mathrm{~g} / \mathrm{kg} \mathrm{BW} \\
6.4 \mathrm{~g} / \mathrm{kg} \mathrm{BW}\end{array}$ & Rats & $\begin{array}{l}70 \% \text { ethanol extract of } \\
\text { lantana leaves has an anti- } \\
\text { inflammatory effect on rat } \\
\text { foot edema. }\end{array}$ & Indonesia & $\begin{array}{l}\text { Sandhiutami et } \\
\text { al, } 2020\end{array}$ \\
\hline Methanol extract & $\begin{array}{l}10 \mathrm{mg} / \mathrm{kg} \mathrm{BW} \\
20 \mathrm{mg} / \mathrm{kg} \mathrm{BW} \\
40 \mathrm{mg} / \mathrm{kg} \mathrm{BW}\end{array}$ & $\begin{array}{l}\text { Swiss } \\
\text { Rats }\end{array}$ & $\begin{array}{l}\text { Methanol extract in lantana } \\
\text { leaves has an anti- } \\
\text { inflammatory effect as } \\
\text { measured by the volume of } \\
\text { edema in rat paws. }\end{array}$ & India & $\begin{array}{l}\text { Ghosh et al, } \\
2010\end{array}$ \\
\hline Ethanol extract & $\begin{array}{l}100 \mathrm{~g} / \mathrm{ml} \\
200 \mathrm{~g} / \mathrm{ml} \\
300 \mathrm{~g} / \mathrm{ml} \\
400 \mathrm{~g} / \mathrm{ml} \\
500 \mathrm{~g} / \mathrm{ml}\end{array}$ & $\begin{array}{l}\text { Albumin } \\
\text { denaturati } \\
\text { on }\end{array}$ & $\begin{array}{l}\text { Lantana camara leaf fraction } \\
\text { extract has significant anti- } \\
\text { inflammatory activity in } \\
\text { inhibiting protein (albumin) } \\
\text { denaturation, therefore } \\
\text { lantana camara has } \\
\text { significant anti-inflammatory } \\
\text { properties. }\end{array}$ & India & $\begin{array}{l}\text { Karthikeyan et } \\
\text { al, } 2020\end{array}$ \\
\hline
\end{tabular}




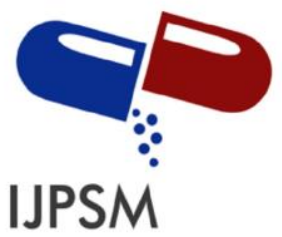

\section{Restia Apriliana et al, Int. Journal of Pharmaceutical Sciences and Medicine (IJPSM), Vol.6 Issue. 8, August- 2021, pg. 144-151}

ISSN: 2519-9889

Impact Factor: 3.426

Research for the anti-inflammatory and antioxidant activity of Lantana camara L has been carried out many times. Ifora et. al., in 2020 tested the anti-inflammatory activity of the ethanol extract of lantana leaves (Lantana camara L.) at a dose of $100 \mathrm{mg} / \mathrm{kg} \mathrm{BW}, 200 \mathrm{mg} / \mathrm{kg} \mathrm{BW}$, and $400 \mathrm{mg} / \mathrm{kg} \mathrm{BW}$. The results showed the activity of Lantana camara L extract on the inflammation inhibitory power of male white rats (Sig < 0.05$)$ and had an effect on the inhibitory power of the cyclooxygenase-2 enzyme in male white rats $(\mathrm{Sig}<0.05)^{[3]}$.

Based on research conducted by Wijaya et. al., in 2017, from four variants of the dose of lantana leaves extract $750 \mathrm{mg} / \mathrm{kgBB}, 1000 \mathrm{mg} / \mathrm{kgBB}, 1250 \mathrm{mg} / \mathrm{kgBB}$ and $1500 \mathrm{mg} / \mathrm{kgBB}$. The effective dose of lantana leaf extract is $1500 \mathrm{mg} / \mathrm{kgBW}$ which has better anti-inflammatory activity in reducing inflammation of the feet of white rats $^{[1]}$.

Research by Sandhiutami et. al., in 2020, showed that 70\% ethanol extract (Lantana camara) has effectiveness as an anti-inflammatory against rat footprint edema. The dose of lantana leaves extract at $3.2 \mathrm{~g} / \mathrm{kg}$ and $6.4 \mathrm{~g} / \mathrm{kg}$ was effective as an anti-inflammatory with a percentage value of $21.44 \%$ and $21.77 \%$ and the effectiveness was $74.57 \%$ and $75.72 \%$, respectively ${ }^{[4]}$. In another study by Ghosh et. al., in 2010, methanol extract of lantana leaves (Lantana camara) at a dose of $10 \mathrm{mg} / \mathrm{kg}, 20 \mathrm{mg} / \mathrm{kg}, 40 \mathrm{mg} / \mathrm{kg}$, had an anti-inflammatory effect as measured by the volume of edema in rat paws ${ }^{[18]}$.

Based on research conducted by Karthikeyen et. al., in 2020, ethanol extract from lantana leaves at doses of $100 \mu \mathrm{g} / \mathrm{ml}, 200 \mu \mathrm{g} / \mathrm{ml}, 300 \mu \mathrm{g} / \mathrm{ml}, 400 \mu \mathrm{g} / \mathrm{ml}, 500 \mu \mathrm{g} / \mathrm{ml}$ had significant anti-inflammatory activity in inhibiting protein (albumin) denaturation. Lantana camara has significant anti-inflammatory properties ${ }^{[21]}$.

Chemical compounds contained in lantana leaves extract (Lantana camara) have anti-inflammatory properties. The benefit can prevent the formation of inflammation. ${ }^{[1]}$ Inflammation is a natural response that occurs in tissue damage. Lantana plant has the potential to be developed as an anti-inflammatory drug because it contains flavonoids, saponins, tannins, and essential oil alkaloids, carbohydrates, proteins, glycosides, oligosaccharides, kinins, steroids, triterpenoids, and sesquiterpenes ${ }^{[2]}$. The presence of anti-inflammatory activity from lantana leaves is allegedly due to the activity of secondary metabolites contained in lantana leaves ${ }^{[4]}$. This was done through phytochemical screening which showed that lantana leaves extract contained flavonoid compounds, alkaloids, tannins, and saponins ${ }^{[7]}$.

The mechanism of flavonoids in inhibiting the process of inflammation occurs in two ways, namely by inhibiting capillary permeability and inhibiting arachidonic acid metabolism so that prostaglandin production is reduced ${ }^{[4]}$. Flavonoids inhibit the secretion of lysosomal enzymes which are mediators of inflammation ${ }^{[1]}$, and also inhibit phosphodiesterase, aldol reductase, monoamine oxidase, protein kinase, DNA polymerase and lipoxygenase ${ }^{[10]}$. Tannins are known to have anti-inflammatory, astringent, antidiarrheal, diuretic, and antiseptic activities ${ }^{[14]}$. Saponins have the ability as cleansers and antiseptics that function to kill or prevent the growth of microorganisms. In addition, it stimulates the formation of collagen, a structural protein that plays a role in the wound healing process ${ }^{[10]}$.

Inhibition of these inflammatory mediators can inhibit the proliferation of the inflammatory process ${ }^{[24]}$. While the anti-inflammatory mechanism of saponins is to inhibit the increase in vascular permeability ${ }^{[25]}$. In addition to flavonoids, tannins also have anti-inflammatory activity. Tannins have antioxidant activity ${ }^{[1]}$. Antioxidants act as an anti-inflammatory in various ways, namely (1) inhibiting the production of oxidants (O2) by neutrophils, monocytes, and macrophages, inhibiting $\mathrm{O} 2$ will reduce the formation of $\mathrm{H} 2 \mathrm{O} 2$ which results in the production of hypochlorous acid ( $\mathrm{HOCl}$ ) and $\mathrm{OH}$ being inhibited. (2) directly inhibit reactive oxidants such as hydroxyl radicals $(\mathrm{OH})$ and hypochlorous acid. The active compounds contained in red betel are thought to be able to help in the healing process of inflammation ${ }^{[12]}$. 


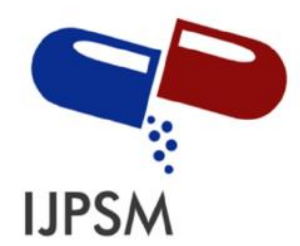

Restia Apriliana et al, Int. Journal of Pharmaceutical Sciences and Medicine (IJPSM),

Vol.6 Issue. 8, August- 2021, pg. 144-151

ISSN: 2519-9889

Impact Factor: 3.426

\subsection{Antioxidants}

Lantana leaves (Lantana camara) contain antioxidants which are summarized in table 2.

Table 2. Summary on antioxidant activity of Lantana camara

\begin{tabular}{|c|c|c|c|c|c|}
\hline Type of Solvent & Compound & $\mathrm{IC}_{50}$ & $\begin{array}{l}\text { Antioxidant } \\
\text { intensity }\end{array}$ & Country & Reference \\
\hline $\begin{array}{l}\text { n-hexane } \\
\text { ethyl acetate } \\
\text { ethanol }\end{array}$ & $\begin{array}{l}\text { Alkaloids } \\
\text { Polyphenols and } \\
\text { steroids } \\
\text { Tannins }\end{array}$ & $\begin{array}{l}153.78 \text { PPM } \\
71.70 \text { PPM } \\
80,96 \text { PPM }\end{array}$ & $\begin{array}{l}\text { Weak } \\
\text { Strong } \\
\text { Strong }\end{array}$ & Indonesia & Mangela et al, 2016 \\
\hline Ethanol & $\begin{array}{l}\text { Polyphenols / } \\
\text { tannins }\end{array}$ & $8,95 \mathrm{ug} / \mathrm{ml}$ & Very strong & Indonesia & $\begin{array}{l}\text { Wahyuningrum et } \\
\text { al ,2021 }\end{array}$ \\
\hline $\begin{array}{l}\text { Soluble fraction } \\
\text { n-hexane }\end{array}$ & Lipids & $67.86 \mu \mathrm{g} / \mathrm{ml}$ & Strong & & \\
\hline $\begin{array}{l}\text { Insoluble } \\
\text { fraction n- } \\
\text { hexane }\end{array}$ & Lipids & $35.03 \mathrm{ug} / \mathrm{ml}$ & Very strong & & \\
\hline $\begin{array}{l}\text { Soluble fraction } \\
\text { ethyl acetate }\end{array}$ & $\begin{array}{l}\text { Flavonoids, } \\
\text { phenolic }\end{array}$ & $68.43 \mu \mathrm{g} / \mathrm{ml}$ & Strong & & \\
\hline $\begin{array}{l}\text { insoluble } \\
\text { fraction }\end{array}$ & $\begin{array}{l}\text { Flavonoids, } \\
\text { phenolic }\end{array}$ & $23.86 \mathrm{ug} / \mathrm{ml}$ & Very strong & & \\
\hline Vitamin C & & $3.99 \mu \mathrm{g} / \mathrm{ml}$ & Very strong & & \\
\hline Distilled water & Phenolic & $42.66 \mathrm{ug} / \mathrm{ml}$ & Very strong & India & Kalita et al, 2012 \\
\hline Methanol & $\begin{array}{l}\text { Phenolic } \\
\text { Flavonoids } \\
\text { Proantoyandin }\end{array}$ & $\begin{array}{l}0,036 \mathrm{pg} / \mathrm{ml} \\
10.7 \mu \mathrm{g} / \mathrm{ml} \\
132.5 \mathrm{pg} / \mathrm{ml}\end{array}$ & $\begin{array}{l}\text { Very strong } \\
\text { Very strong } \\
\text { Moderate }\end{array}$ & India & Bhakta et al, 2009 \\
\hline
\end{tabular}

Based on research conducted by Mangela et. al., in 2006, the antioxidant activity of lantana leaves for nhexane, ethyl acetate and ethanol extracts, respectively are as follows: $153.78 \mathrm{ppm}, 71.70 \mathrm{ppm}$, and $80.96 \mathrm{ppm}$. The antioxidant activity of lantana leaves in the n-hexane extract was weak, while the ethyl acetate and ethanol extracts were strong. The content of compounds in lantana leaves in the n-hexab extract contained alkaloids and terpenoids, in ethyl acetate, there were polyphenols/tannins and steroids while in ethanol there were polyphenols/tannins ${ }^{[2]}$. 


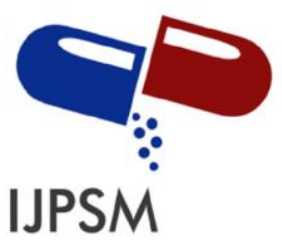

\section{Restia Apriliana et al, Int. Journal of Pharmaceutical Sciences and Medicine (IJPSM), Vol.6 Issue. 8, August- 2021, pg. 144-151}

ISSN: 2519-9889

Impact Factor: 3.426

Wahyuningrum et. al., research in 2021 showed that the antioxidant activity of lantana camara for ethanol extract $8.95 \mathrm{~g} / \mathrm{ml}$ was very strong, the soluble fraction $\mathrm{n}$-hexane $67.86 \mathrm{~g} / \mathrm{ml}$ was strong, the insoluble fraction $\mathrm{n}$-hexane $35.03 \mathrm{~g} / \mathrm{ml}$ very strong, the soluble fraction of ethyl acetate $68.43 \mathrm{~g} / \mathrm{ml}$ was strong, the insoluble fraction of ethyl acetate $23.86 \mathrm{~g} / \mathrm{ml}$ was very strong and vitamin C $3.99 \mathrm{~g} / \mathrm{ml}$ was very strong ${ }^{[6]}$.

Table 3 IC50 value data based on antioxidant intensity ${ }^{[22]}$.

\begin{tabular}{ll}
\hline Antioxidant intensity & $\mathbf{I C}_{\mathbf{5 0}}$ value \\
\hline Very strong & $<50$ \\
Strong & $51-100$ \\
Moderate & $101-250$ \\
Weak & $251-500$ \\
Inactive & $>501$ \\
\hline
\end{tabular}

Based on research conducted by Kalita et. al., 2012, the antioxidant activity of lantana leaves from $42.66 \mathrm{~g} / \mathrm{ml}$ distilled water is very strong, in the distilled water extract of lantana leaves there are phenolic compounds ${ }^{[5]}$. In another study by Bhakta et al 2009, methanol extract of lantana leaves, phenolic compounds $0.036 \mathrm{~g} / \mathrm{ml}$ are very strong, flavonoids $10.7 \mathrm{~g} / \mathrm{ml}$ is very strong, proantoyanding $135.5 \mathrm{~g} / \mathrm{ml}$ is moderate ${ }^{[24]}$.

The presence of antioxidant activity is thought to be due to the presence of secondary metabolites contained in lantana leaves. This was obtained from the results of the lantana leaves extract group containing flavonoids, alkaloids, paolofeno/tannins, steroids, and terpenoids ${ }^{[2]}$. Flavonoids are one of the most common examples of polyphenols found in plants. Polyphenolic compounds have antioxidant activity by inhibiting oxidation reactions by scavenging free radicals ${ }^{[26]}$. The more polyphenol components, the higher the antioxidant $\operatorname{activity}^{[25]}$.

\section{Conclusion}

Chemical compounds contained in lantana leaves (Lantana camara) are useful as an anti-inflammatory. The anti-inflammatory activity of betel leaf extract is thought to be due to the presence of flavonoid compounds, saponins and tannins. The mechanism of flavonoids in inhibiting the process of inflammation is done in two ways, namely by inhibiting capillary permeability and inhibiting arachidonic acid metabolism so that prostaglandin production is reduced. Flavonoids also inhibit the secretion of lysosomal enzymes which are mediators of inflammation. Inhibition of these inflammatory mediators can inhibit the proliferation of the inflammatory process.

From the results of several studies used, the lantana plant has compounds that have the potential as antioxidants, namely polyphenol compounds that have antioxidant activity by inhibiting oxidation reactions by capturing free radicals. The more polyphenol components, the higher the antioxidant activity. Lantana camara has the highest antioxidant activity with a value of $0.036 \mathrm{~g} / \mathrm{ml}$. 


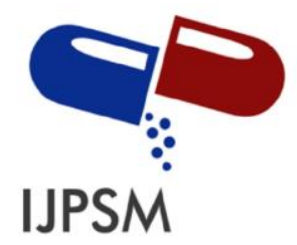

Restia Apriliana et al, Int. Journal of Pharmaceutical Sciences and Medicine (IJPSM), Vol.6 Issue. 8, August- 2021, pg. 144-151

ISSN: 2519-9889

Impact Factor: 3.426

\section{Acknowledgements}

This work was supported by the Department of Pharmacology and Clinical Pharmacy, School of Pharmaceutical Science Padang (STIFARM Padang). Faculty of Pharmacy Andalas University (UNAND Padang).

\section{References}

[1] AY Wijaya, MA Masruhim, and H. Kuncoro, "ANTINFLAMMATION ACTIVITIES OF THE EXTRACT OF THINGS (Lantana Camara Linn) IN WHITE RATS (Rattus Norvegicus)," J. Sains and Health., vol. 1, no. 6, pp. 284-289, 2016, doi:10.25026/jsk.v1i6.63.

[2] O. Mangela, R. Ahmad, Musafira, "Study of Antioxidant Activity of Tembelekan (Lantana camara L) Leaf Extract Based on Level Polar Solvent" vol. 2(3):16-23, 2016.

[3] I. Ifora, F. Fauziah, and SA Mayora, "Anti-inflammatory Activity and Inhibition of Cyclooxygenase-2 Ethanol Extract of Tembelekan Leaves (Lantana camara L.),” J. Farm. Higea, vol. 12, no. 1, pp. 3239, 2020.

[4] NMD Sandhiutami, Y. Desmiaty, NS Darmastuti, and F. Muhammad, "The Potential of Tembelekan Leaves (Lantana Camara Linn.) As Anti-platelet Aggregation and Anti-Inflammation In Vivo," J. Indonesian Pharmaceutical Sciences., vol. 18, no. 2, pp. 3-8, 2020.

[5] S. Kalita, G. Kumar, L. Karthik, and KVB Rao, "In vitro antioxidant and DNA damage inhibition activity of aqueous extract of Lantana camara L. (Verbenaceae) leaves," Asian Pac. J. Trop. biomed., vol. 2, no. 3 SUPPL., 2012, doi: 10.1016/S2221-1691(12)60476-6.

[6] R. Wahyuningrum, G. E, and P. IN, "Antimicrobial and Antioxidant Activity of Extract and Fraction of Tembelekan Leaves (Lantana camara L.)," J. Farm. Udayana, vol. 10, no. 1, p. 107, 2021, doi:10.24843/jfu.2021.v10.i01.p13.

[7] S. Kumar, R. Sandhir, and S. Ojha, "Evaluation of antioxidant activity and total phenol in different varieties of Lantana camara leaves," BMC Res. Notes, vol. 7, no. 1, pp. 1-9, 2014, doi:10.1186/17560500-7-560.

[8] S. Agnihotri, S. Wakode, and A. Agnihotri, "An overview on anti-inflammatory properties and chemoprofiles of plants used in traditional medicine,” Indian J. Nat. Prod. resort., vol. 1, no. 2, pp. 150-167, 2010.

[9] N. Anisa, NA Amaliah, PM Al Haq, and AN Arifin, "The Anti-Inflammatory Effectiveness of Mango Leaves (Mangifera Indica) Against Second Degree Burns," Sainsmat J. Ilm. Knowledge Science. Nature, vol. 8, no. 1, p. 1, 2019, doi:10.35580/sainsmat81101182019.

[10] AIN Male and W. Rat, “Abdul Aziz Setiawan, Sefi Megawati, Dinda Nisa 2016,” vol. III, no. 1, pp. 16, 2016.

[11] AP Zahra and N. Carolia, "Non-steroidal Anti-Inflammatory Drugs (NSAIDs): Gastroprotective vs Cardiotoxic," Majority, vol. 6, pp. 153-158, 2017.

[12] INE Lister, CN Ginting, E. Girsang, ED Nataya, AM Azizah, and W. Widowati, "Hepatoprotective properties of red betel (Piper crocatum Ruiz and Pav) leaves extract towards H2O2-induced HepG2 cells via anti-inflammatory, antinecrotic, antioxidant potency," Saudi Pharm. J., vol. 28, no. 10, pp. 1182-1189, 2020, doi: 10.1016/j.jsps.2020.08.007.

[13] DR Laksmitawati et al., "Anti-inflammatory effects of Anredera cordifolia and piper crocatum extracts on lipopolysaccharide-stimulated macrophage cell line," Bangladesh J. Pharmacol., vol. 12, no. 1, pp. 35-40, 2017, doi:10.3329/bjp.v12i1.28714.

[14] A. Fitriyani, L. Winarti, S. Muslichah, and D. Nuri, "Anti-Inflammatory Test of Methanol Extract of Red Betel Leaf (Piper crocatum Ruiz \& Pav) on White Rats," Maj. Traditional Medicine., vol. 16, no. 1, p. 2011, 2011. 


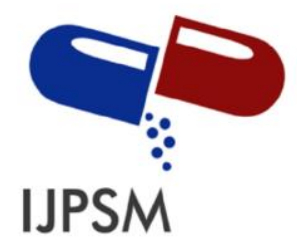

Restia Apriliana et al, Int. Journal of Pharmaceutical Sciences and Medicine (IJPSM), Vol.6 Issue. 8, August- 2021, pg. 144-151

ISSN: 2519-9889

Impact Factor: 3.426

[15] K. Idacahyati, T. Nofianti, GA Aswa, and M. Nurfatwa, "Relationship of the Incidence Rate of NonSteroid Anti-Inflammatory Side Effects with Age and Gender," J. Farm. And Indonesian Pharmaceutical Sciences., vol. 6, no. 2, p. 56, 2020, doi:10.20473/jfiki.v6i22019.56-61.

[16] Suprapto, A. Wahyu Budi Aji, M. Iqbal Rushanfikri, and A. Rachmah Afrizal, "Anti-inflammatory Napolion (Nanoparticle Lotion) Formulation Combination of Gelenggang Leaf Extract and Betel Red Anti-inflammatory Napolion (Nanoparticles Lotion) Formulation Combination of Gelenggang Leaf Extract and Red Bethel," J. Farm. (Journal of Pharmacy), vol. 1, no. 1, pp. 1-9, 2019, [Online]. Available: https://ojs.stikesnas.ac.id/index.php/jf/article/view/68.

[17] O. Oyedapo, "Red blood cell membrane stabilizing potentials of extracts of Lantana camara and its fractions," Int. J. Plant Physiol. biochem., vol. 2, no. October, pp. 46-51, 2010, [Online]. Available: http://www.academicjournals.org/ijppb/PDF/PDF 2010/Oct/Oyedapo et al.pdf.

[18] S. Ghosh, M. Das Sarma, A. Patra, and B. Hazra, "Anti-inflammatory and anticancer compounds isolated from Ventilago madraspatana Gaertn., Rubia cordifolia Linn. and Lantana camara Linn.," $J$. Pharm. Pharmacol., vol. 62, no. 9, pp. 1158-1166, 2010, doi: 10.1111/j.2042-7158.2010.01151.x.

[19] M. Suwertayasa, W. Bodhy, and H. Jaya Edy, "Antipyretic Test of Ethanol Extract of Tembelekan Leaves (Lantana Camara L.) in Wistar Male White Rats," PHARMACON J. Ilm. Farms., vol. 2, no. 3, pp. 45-49, 2013.

[20] L. Rijai, "The Potential of the Tembelekan Plant (Lantana camara Linn) as a Potential Source of Pharmaceutical Ingredients," J. Trop. Pharm. Chem., vol. 2, no. 4, pp. 203-211, 2014, doi:10.25026/jtpc.v2i4.70.

[21] M. Karthikeyan, D. Mk, A. Rp, K. Fayis, R. Pk, and S. Rc, "Phytochemical analysis and evaluation of in vitro anti-Inflammatory activity of Lantana camara L," vol. 3, no. 4, pp. 833-836, 2020.

[22] GA Wandita and I. Musrifoh, "Article Review: Zingiberaceae Tribe Plants That Have Antioxidant Activity," Farmaka, vol. 16, no. 2, pp. 564-571, 2018.

[23] F. Ulviani, Y. Yusriadi, and K. Khaerati, "Effect Of Red Belt Leaf (Piper Crocatum Ruiz \& Pav) Extract Gel On Burns Healing In Rabbit (Oryctolagus cuniculus)," J. Farms. Galen. (Galenika J. Pharmacy), vol. 2, no. 2, pp. 103-110, 2016, doi:10.22487/j24428744.2016.v2.i2.5977.

[24] D. Bhakta and D. Ganjewala, "Effect of Leaf Positions on Total Phenolics, Flavonoids and Proanthocyanidins Content and Antioxidant Activities in Lantana Camara (L)," J. Sci. res., vol. 1, no. 2, pp. 363-369, 2009, doi:10.3329/jsr.v1i2.1873.

[25] Y. Mulyani and L. Febiani, "Review Of The Article Of The Bandotan (Ageratum Conyzoides Linn.) Plant As Anti-Bactery, Antioxidant And Anti-Inflammatory. Review Of The Article Of Bandotan (Ageratum conyzoides Linn.) 5, no. 1, pp. 1-19, 2021. 